\title{
Effect of Cutting Time on the Performance of Alfalfa (Medicago sativa L.) Genotypes Cropped in Arid Environment
}

\author{
Samir Tlahigi, ${ }^{1,2 *}$, Inès Karmous ${ }^{2,3}$, Mustapha Gorai ${ }^{2,4}$, Takwa Jaouadi², \\ Mohamed Loumerem ${ }^{1}$ \\ ${ }^{1}$ Dry Land and Oases Cropping Laboratory, Arid Land Institute of Medenine (IRA), Medenine, Tunisia \\ ${ }^{2}$ Department of Environmental Sciences, Insitute of Applied Biology of Medenine (ISBAM), \\ University of Gabes, Tunisia \\ ${ }^{3}$ Plant Toxicology and Molecular Biology of Microorganisms, Faculty of Sciences of Bizerta, Zarzouna, Tunisia \\ ${ }^{4}$ Unit of Valorisation of Active Biomolecules, Insitute of Applied Biology of Medenine, \\ University of Gabes, 4119 Medenine, Tunisia
}

Received: 9 March 2020

Accepted: 28 June 2020

\begin{abstract}
There have been many challenges for plant science researchers to overcome the difficulties associated with soil, climate and environmental sucessful conditions, in order to improve crops quality, yields and productivity. The present study aimed to provide new insights into alfalfa germplasm in order to improve tolerance to arid conditions, along with high yield potential and forage quality. We compared the effect of harvesting time on forage yield and nutritional quality of eight alfalfa genotypes of different origins (native, selected and introduced). The results showed significant $(\mathrm{p}<0.05)$ genetic variability among the genotypes for the agro-morphological traits; dry matter yield, total plant height, number- and length of internodes at different harvesting times. Besides, harvesting at different phenological stages determined the biochemical composition in dry matter, ash, crude proteins, total soluble proteins and sugars and free amino acids. Our results, based on the multivariate cluster analysis and principal component analysis (PCA)-biplot may suggest the genotypes of alfalfa well adapted to stressful environments outside oasis of arid regions. This may bring insights into their use in culture or in breeding programs in attempt to improve adaptability of alfalfa crops to environmental arid conditions.
\end{abstract}

Keywords: alfaalfa, arid environment, forage yield, genotypes, nutritional quality

*e-mail: samirtlahig@gmail.com 


\section{Introduction}

Alfalfa (Medicago sativa L.) is one of the most valuable crops, owing to its considerable contribution to sustainable agriculture and its multiple agronomic and environmental interests [1, 2]. It is used in animal food for its remarkable nutritional composition [3], rich in proteins, minerals, antioxidants and vitamins [4], as well as polyphenolic compounds [5]. Besides, it is known by its ability to adapt to diverse environmental stress conditions such as drought, cold, high temperature and salinity of irrigation water and soil, by dint of the development of root system [6].

However, yield and nutritional quality of alfalfa seeds and forage vary according to many factors, including variety, pedoclimate conditions, technology used, and number of cuts [7]. Alfalfa expansion is limited by various environmental stressful conditions such as drought, water shortage, salinity of soil and water and potentially toxic elements $[8,9]$. In addition, peasants and their oases are under heavy pressure from a number of interlinked biophysical and socioeconomics factors affecting the fragile sustainability of the oasis socio-ecosystems. Under such adverse environment, developing appropriate cultural practices to reverse these negative effects should definitely be sustained by a delicate study of the genetic diversity within populations. Hence, interests were raised in order to improve alfalfa forage quality, while maintaining high yield potential and adaptive responses to arid conditions, and to unpredictable scenarios of climate change [1].

In this context, the main goal of the present study was to find a tradeoff between the quality and the yield of alfalfa germplasm, via investigating the potential effect of harvesting time on some agro-morphological and biochemical traits of alfalfa grown on field under arid conditions outside oasis environment. The present study described the possible interference between the harvesting time on the nutritional quality and forage yield within eight alfalfa genotypes. Indeed, we analyzed the agro-morphological traits and parameters of nutritive values (total soluble proteins, crude proteins, soluble carbohydrates and free amino acids), and tolerance aptitude of the genotypes was compared using multivariate cluster and principal component analyses.

\section{Experimntal}

\section{Study Area, Plant Material and Experimental Design}

This research was conducted on alfalfa plants grown on the experimental field of Dry Land and Oases Cropping Laboratory in the Arid Land Institute

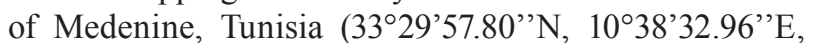
altitude $16 \mathrm{~m}$ ). The soil was characterized by a texture composed of $80 \%$ sand, $15 \%$ silt and $5 \%$ clay. Its physico-chemical characteristics were; total $(9.96 \%)$ and active (5.33\%) limestone, total nitrogen $(\mathrm{N}, 0.03 \%)$, organic matter (OM, 0.95\%), electric conductivity EC $\left(7.81 \mathrm{mS} \mathrm{cm}^{-1}\right)$, apparent density ad (1.51), potassium $(\mathrm{K}, 53.33 \mathrm{mg} \mathrm{Kg})$ and sodium $(\mathrm{Na}$, $\left.12.94 \mathrm{mg} \mathrm{Kg}{ }^{-1}\right)$. Eight alfalfa genotypes of different origins were evaluated: local (i) "Gabes" $(G A B)$ and "Chenini" (CHE); (ii) synthetic genetic material "IRA", and (iii) introduced ("Ameristand801S" (AME), "Bami" $(B A M)$, "Prosementi" (PRO), "Tamentit" (TAM) and "Tata" (TAT). "GAB" was putatively defined as the most performant local landrace under oasis conditions; "CHE" which was randomly sampled from a local producer; "IRA" a synthetic genetic material resulting from a breeding program on basis of poly-cross progeny performance, held in the Dry lands and Oasis Cropping Laboratory of the Arid Land Institute of Médenine in Tunisia; and five exotic genotypes " $A M E$ ", "BAM", "PRO", "TAM" and "TAT" introduced for their putatively salt tolerance, in order to avoid inbreeding risk and improve heterosis (Table 1).

The experiment was performed using Randomized Complete Block Design (eight blocks). In each block $(2.8 \mathrm{~m} \times 1.9 \mathrm{~m})$, alfalfa plants of eight genotypes (20 plants per genotype, Table 1) were grown in row spacing of $15 \mathrm{~cm}$, with similar distances between plants along the length of the row. Borderlines of each block were sown using "GAB" seeds and considered as buffer zone to reduce mutual effects. Irrigations

Table 1. Description of eight genotypes of alfalfa (Medicago sativa L.) and their geographical origins.

\begin{tabular}{|c|c|c|c|}
\hline Name & Code & Origin & Description \\
\hline Chenini & CHE & Tunisia & Population (selected randomly from oasis of Chenini) \\
\hline$I R A$ & $I R A$ & Tunisia & Bred population (Most performant in arid areas outside oasis) \\
\hline Gabes & $G A B$ & Tunisia & Population (Most performant in oasis) \\
\hline Prosementi & $P R O$ & Italy & Variety (exotic, sensible to salinity) \\
\hline Tata & $T A T$ & Morocco & Variety (exotic, putatively tolerant to salinity) \\
\hline Tamentit & $T A M$ & Algeria & Variety (exotic, tolerant to salinity) \\
\hline Bami & $B A M$ & Iran & Variety (exotic, tolerant to salinity) \\
\hline Ameristand $801 S$ & $A M E$ & USA & Variety (exotic, tolerant to salinity) \\
\hline
\end{tabular}


Table 2. Climatic data during trial period (from January to June, 2018) along the experimental period under open field conditions.

\begin{tabular}{|c|c|c|c|c|c|c|c|}
\hline & $\mathrm{T}\left({ }^{\circ} \mathrm{C}\right)$ & $\mathrm{TM}\left({ }^{\circ} \mathrm{C}\right)$ & $\mathrm{Tm}\left({ }^{\circ} \mathrm{C}\right)$ & $\mathrm{H}(\%)$ & $\mathrm{PP}(\mathrm{mm})$ & $\mathrm{V}\left(\mathrm{Km} \mathrm{h}^{-1}\right)$ & $\mathrm{VM}\left(\mathrm{Km} \mathrm{h}^{-1}\right)$ \\
\hline January & 13.6 & 19.2 & 8.9 & 55.6 & 0.0 & 8.2 & 14.3 \\
\hline February & 12.8 & 18 & 8.5 & 62.6 & 24.65 & 8.9 & 15.6 \\
\hline March & 19.3 & 25.5 & 13.2 & 39.8 & 17.01 & 12.8 & 20.5 \\
\hline April & 21.9 & 26.9 & 16.7 & 50.8 & 15.49 & 2.4 & 18.0 \\
\hline May & 23.3 & 28.3 & 18.2 & 54.2 & 73.16 & 11.0 & 17.2 \\
\hline June & 26.4 & 33.0 & 20.9 & 52.1 & 0.25 & 9.6 & 16.7 \\
\hline
\end{tabular}

T: Average Temperature $\left({ }^{\circ} \mathrm{C}\right)$, TM: Maximum Temperature $\left({ }^{\circ} \mathrm{C}\right), \mathrm{Tm}$ : Minimum Temperature $\left({ }^{\circ} \mathrm{C}\right)$, H: Average relative humidity $(\%)$, PP: Total rainfall and/or snowmelt $(\mathrm{mm}), \mathrm{V}$ : Average wind speed $\left(\mathrm{Km} \mathrm{h}^{-1}\right), \mathrm{VM}$ : Maximum sustained wind speed $\left(\mathrm{Km} \mathrm{h}^{-1}\right)$.

were distributed weekly with equal quantities of water $\left(50 \mathrm{dm}^{3} \mathrm{~m}^{-2}\right.$ per irrigation) with $\mathrm{EC}=8.34{\mathrm{dS} \mathrm{cm}^{-1}}^{-1}$ during the trial period (from January to June 2018). Table 2 summarizes the climatic conditions during this trial period, including the experimental period under open field conditions. Mean monthly rainfall ranges between 15.49 and $73.16 \mathrm{~mm}$ during the period of the experiment. Mean monthly temperature ranges between 13.6 and $26.4^{\circ} \mathrm{C}$, with a minimum of $8.5^{\circ} \mathrm{C}$ in February and $33.0^{\circ} \mathrm{C}$ maximum in June. Cuttings were carried out at four dates corresponding to various phenological stages as follows:

- Cutting 1 on 08/02/2018 corresponding to full winter (Pre-bud stage);

- Cutting 2 on 03/04/2018 corresponding to end of winter and beginning of spring (one-tenth);

- Cutting 3 on 26/04/2018 corresponding to full spring (50\% blooming); and

- Cutting 4 on 04/06/2018 corresponding to end of spring (Full blooming).

\section{Agro-Morphological Measurements}

The growth of plants was evaluated in situ at the same conditions, by measuring the following parameters: plant height, number internodes, length of internodes and total fresh mass (FM). Adjusted dry matter yield (adjusted DM yield) was calculated taking into account the mortality out of total number of 20 plants (corresponding to $1 \mathrm{~m}^{2}$ of surface) due to environmental effect (mainly cumulative saline irrigation water effect) after two years from sowing time. Fresh samples (a mixture of leaves, stems and flowers if present) were kept at $-20^{\circ} \mathrm{C}$ for biochemical analyses. One gram of fresh biomass of each genotype was placed at $105^{\circ} \mathrm{C}$ for 24 hours, to get dry biomass (DM). Mineral biomass, referred as ash, was determined after combustion at $550^{\circ} \mathrm{C}$ in the oven during 6 hours, and expressed as percentage of DM.

\section{Biochemical Analyses}

Total soluble proteins were extracted $(1: 10, \mathrm{w} / \mathrm{v})$ in Tris- $\mathrm{HCl} 0.125 \mathrm{M}, \mathrm{pH}$ 6.8, containing SDS 4\% and $\beta$-mercaptoethanol $5 \%$, and concentration was determined according to Bradford (1976) [10], using bovine serum albumin as standard protein.

Free amino acids and total soluble sugars were extracted in ethanol, and levels were determined, using ninhydrin $1.5 \%$ and anthrone $0.2 \%$, respectively [11, 12]. A standard curve was performed using glycine and glucose, respectively, for amino acids and sugars.

Kjeldahl method was used to determine the total nitrogen content in studied samples $(0.5 \mathrm{~g}$ of dry biomass) [13]. A control reaction (in the absence of sample) was carried as reference. The percentage of nitrogen was calculated as $\% \mathrm{~N}=100 \times(\mathrm{VHCl}$ for sample-V0) $\times 0.1(\mathrm{~N}) \times 0.140 / \mathrm{m}(\mathrm{g})$. V0 was referred to the volume of $\mathrm{HCl}$ used in titration.

\section{Statistical Analysis}

Statistical analyses were performed with SPSS 23.0 software. Data were subjected to analysis of variance (two-ways) ANOVA using GLM procedure $(\alpha=0.05)$ to test the main effects of Cutting (C), Genotype (G) and their interaction $(\mathrm{C} \times \mathrm{G})$. Classification of genotypes for each individual evaluated trait was realized by comparing means using Duncan multi-range test $(\alpha=0.05)$. Graphics were performed using GraphPad Prism V5.0. The structure of genetic variability among genotypes was analyzed using hierarchical cluster analysis (HCA) and principal component analysis (PCA). The independent variables were centered and standardized.

\section{Results and Discussion}

\section{Results}

\section{Effect of Harvest Time on Yield and Growth Attributes}

The evaluation of the agro-morphological traits in alfalfa plants revealed high significant differences for plant height, length- and number of internodes under the effects of genotype $(\mathrm{G})$, cutting time $(\mathrm{C})$ and interaction 
Table 3. Agro-morphological traits (plant height, number of internodes, length of internodes) of eight genotypes of alfalfa plants at four cutting dates: "Pre-bud stage", "One tenth bloom", "50\% blooming" and "Full blooming".

\begin{tabular}{|c|c|c|c|c|c|}
\hline \multirow{2}{*}{ Genotypes } & \multicolumn{5}{|c|}{ Plant height (cm) } \\
\hline & Pre-bud stage & One tenth bloom & $50 \%$ blooming & Full blooming & $C V(\%)$ \\
\hline$A M E$ & $17.20 \pm 3.12^{e}$ & $41.40 \pm 3.41^{b c}$ & $65.80 \pm 6.36^{b}$ & $79.20 \pm 4.75^{b c}$ & 53.79 \\
\hline$B A M$ & $42.60 \pm 2.73^{a b}$ & $54.00 \pm 4.89^{a b c}$ & $62.00 \pm 6.41^{b}$ & $88.80 \pm 5.65^{a b}$ & 31.77 \\
\hline CHE & $23.40 \pm 1.99^{d e}$ & $35.60 \pm 4.95^{c}$ & $64.80 \pm 2.99^{b}$ & $80.80 \pm 3.10^{b c}$ & 51.45 \\
\hline$G A B$ & $44.60 \pm 3.19^{a b}$ & $62.80 \pm 8.10^{a}$ & $84.60 \pm 4.70^{a}$ & $98.80 \pm 3.47^{a}$ & 32.84 \\
\hline$I R A$ & $37.30 \pm 3.02^{b c}$ & $50.60 \pm 9.44^{a b c}$ & $60.80 \pm 1.02^{b}$ & $85.60 \pm 6.55^{a b}$ & 34.87 \\
\hline$P R O$ & $41.60 \pm 2.69^{b}$ & $61.60 \pm 7.72^{a b}$ & $82.80 \pm 4.73^{a}$ & $90.40 \pm 5.72^{a b}$ & 31.86 \\
\hline TAM & $29.80 \pm 1.59^{c d}$ & $36.00 \pm 3.70^{c}$ & $69.20 \pm 4.24^{a b}$ & $67.40 \pm 5.28^{c}$ & 40.73 \\
\hline$T A T$ & $51.00 \pm 4.25^{a}$ & $48.70 \pm 6.01^{a b c}$ & $72.40 \pm 6.88^{a b}$ & $84.00 \pm 3.96^{a b}$ & 26.65 \\
\hline $\operatorname{ANOVA}(\alpha=0.05)$ & $* * *$ & $*$ & $* *$ & $* *$ & \\
\hline Genotype & & & $* * *$ & & \\
\hline Cutting & & & $* * *$ & & \\
\hline \multirow{2}{*}{ Genotype $\times$ Cutting } & & & $*$ & & \\
\hline & \multicolumn{5}{|c|}{ Number of internodes } \\
\hline$A M E$ & $5.80 \pm 0.66^{c}$ & $10.80 \pm 1.36^{a b}$ & $11.00 \pm 0.30^{a}$ & $12.00 \pm 0.63^{b}$ & 28.11 \\
\hline$B A M$ & $7.20 \pm 0.58^{a b c}$ & $14.60 \pm 0.93^{a b}$ & $13.00 \pm 0.47^{a}$ & $15.00 \pm 0.84^{a b}$ & 28.96 \\
\hline CHE & $6.00 \pm 0.71^{c}$ & $10.40 \pm 1.66^{b}$ & $11.80 \pm 0.15^{a}$ & $14.60 \pm 0.40^{a b}$ & 33.52 \\
\hline$G A B$ & $8.20 \pm 0.37^{a}$ & $13.20 \pm 2.52^{a b}$ & $12.40 \pm 0.45^{a}$ & $15.80 \pm 1.46^{a}$ & 25.43 \\
\hline $\operatorname{IRA}$ & $6.20 \pm 0.80^{b c}$ & $12.60 \pm 0.98^{a b}$ & $11.20 \pm 0.32^{a}$ & $14.60 \pm 0.51^{a b}$ & 32.13 \\
\hline$P R O$ & $7.40 \pm 0.24^{a b c}$ & $15.60 \pm 1.29^{a}$ & $13.60 \pm 0.16^{a}$ & $13.20 \pm 1.66^{a b}$ & 28.33 \\
\hline TAM & $7.60 \pm 0.81^{a b c}$ & $11.20 \pm 1.77^{a b}$ & $11.60 \pm 0.22^{a}$ & $11.40 \pm 1.44^{b}$ & 18.25 \\
\hline TAT & $8.00 \pm 0.32^{a b}$ & $11.20 \pm 0.73^{a b}$ & $11.40 \pm 0.46^{a}$ & $12.80 \pm 1.16^{a b}$ & 18.70 \\
\hline $\operatorname{ANOVA}(\alpha=0.05)$ & $*$ & $*$ & $N S$ & $*$ & \\
\hline Genotype & \multicolumn{5}{|c|}{$* *$} \\
\hline Cutting & \multicolumn{5}{|c|}{$* * *$} \\
\hline \multirow[t]{2}{*}{ Genotype $\times$ Cutting } & \multicolumn{5}{|c|}{ * } \\
\hline & \multicolumn{5}{|c|}{ Length of internodes (cm) } \\
\hline$A M E$ & $4.00 \pm 0.47^{d}$ & $3.90 \pm 0.75^{a b}$ & $6.70 \pm 0.37^{a b}$ & $7.33 \pm 0.56^{a}$ & 32.64 \\
\hline$B A M$ & $8.30 \pm 0.51^{b}$ & $4.30 \pm 0.60^{a b}$ & $8.80 \pm 0.51^{a}$ & $7.30 \pm 0.53^{a}$ & 28.09 \\
\hline CHE & $4.20 \pm 0.25^{d}$ & $4.80 \pm 0.85^{a b}$ & $8.40 \pm 0.98^{a b}$ & $6.77 \pm 0.19^{a}$ & 31.72 \\
\hline$G A B$ & $7.50 \pm 0.69^{b}$ & $5.00 \pm 0.71^{a b}$ & $8.60 \pm 0.81^{a b}$ & $6.40 \pm 0.38^{a}$ & 22.39 \\
\hline $\operatorname{IRA}$ & $5.60 \pm 0.29^{c d}$ & $4.40 \pm 0.51^{a b}$ & $8.00 \pm 0.35^{a b}$ & $7.43 \pm 0.54^{a}$ & 26.10 \\
\hline$P R O$ & $7.00 \pm 0.71^{b c}$ & $4.20 \pm 0.12^{a b}$ & $7.80 \pm 1.16^{a b}$ & $7.20 \pm 0.69^{a}$ & 24.48 \\
\hline TAM & $5.40 \pm 0.24^{c d}$ & $3.10 \pm 0.10^{b}$ & $7.30 \pm 0.70^{a b}$ & $6.00 \pm 0.20^{a}$ & 32.22 \\
\hline$T A T$ & $10.00 \pm 1.05^{a}$ & $5.60 \pm 1.03^{a}$ & $6.40 \pm 0.40^{b}$ & $7.60 \pm 0.65^{a}$ & 25.92 \\
\hline $\operatorname{ANOVA}(\alpha=0.05)$ & $* * *$ & $*$ & $*$ & $N S$ & \\
\hline Genotype & \multicolumn{5}{|c|}{$* * *$} \\
\hline Cutting & \multicolumn{5}{|c|}{$* * *$} \\
\hline
\end{tabular}


Table 3. Continued.

\begin{tabular}{l}
\hline Genotype $\times$ Cutting \\
Genotypes were designed by AME: Ameristand801S; BAM: Bami; CHE: Chenini; \\
GAB: Gabes; IRA: IRA; PRO: Prosementi; TAM: Tamentit; TAT: Tata. Letters $a-c$ denote statistical classes of genotypes obtained \\
using Duncan test, for each trait. Significant differences were designed according to $P$ values by $*: P<0.05,{ }^{* *}: P<0.01,{ }^{* *}:$ \\
$P<0.001$ and NS (non-significant): $>0.05$.
\end{tabular}

(genotype $\times$ cutting) $(\mathrm{G} \times \mathrm{C})$ (Table 3$)$. Furthermore, these traits showed high coefficient of variation $(C V>10 \%)$, suggesting them being sufficiently homogenous for the evaluated traits (Table 3). At prebud stage, the test of comparison of averages showed that $G A B$ registered the highest number of internodes, $T A T, B A M$ and $G A B$ expressed high elongation of internodes, versus minimum values recorded by $A M E$ and $C H E$. This classification was modified in the next cutting date, since all genotypes demonstrated proximate values of number of internodes, except $P R O$ and $C H E$ (highest and lowest values) (Table 3). At 50\% blooming stage (third harvest), all genotypes exhibited maximum of shoot length and elongation of internodes, versus a constant number of internodes. These attributes became almost stable at full blooming stage (fourth harvest) (Table 3).
Our results also showed highly significant differences among genotypes at all harvesting times (Fig. 1). Besides, alfalfa yields appear to be drastically affected by mortality of plants (see adjusted DM yields, Fig. 1). At the first cutting, $B A M$ followed by $T A T$ reached the highest DM yields (ca.27\% of contribution to the total yield for each genotype) (Fig. 1a). At the third harvest, yields of all genotypes were significantly enhanced and the highest values of DM yield were produced by $G A B$ followed by $B A M$, corresponding to $29 \%$ and $19 \%$ of contribution to the total yield, respectively (Fig. 1c). At the last harvest, DM yield decreased in comparison with results of cutting $\mathrm{N}^{\circ} 3$; however, $G A B$ displayed most contribution to the total yield, together with $B A M$ (20\% for each genotype) (Fig. 1d). Besides, alfalfa yields appear to be drastically affected by mortality of plants. The adjusted DM yield
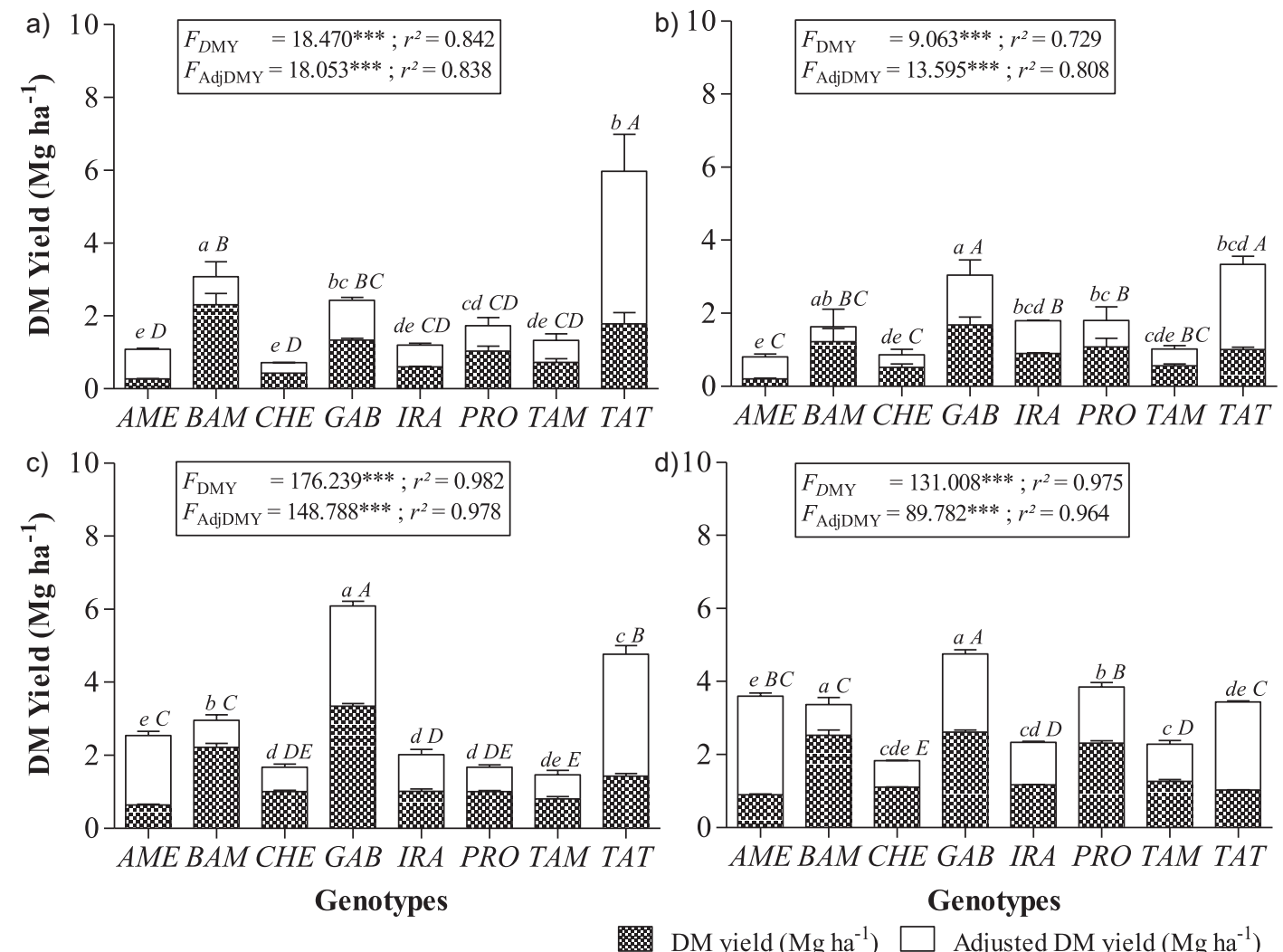

Fig. 1. Yield of eight genotypes of alfalfa plants at four different cutting dates: a) Pre-bud stage, b) One tenth bloom, c) 50\% blooming and d) Full blooming. Adjusted fresh matter yield was calculated taking in account mortality out of total number of 20 plants (corresponding to $1 \mathrm{~m}^{2}$ of surface). Genotypes were designed by AME: Ameristand801S; BAM: Bami; CHE: Chenini; GAB: Gabes; IRA: IRA; PRO: Prosementi; TAM: Tamentit; TAT: Tata. " $F$ " denote values of Fisher test. Letters $a-f$ and $A-F$ denote statistical classes of genotypes obtained using Duncan test, respectively, for dry matter yield and adjusted dry matter yield. Significant differences were designed according to $P$ values by *: $P<0.05, * *: P<0.01$ and $* * *: P<0.001$. 
Table 4. Changes in dry matter (DM) and ash contents of eight genotypes of alfalfa plants at four cutting dates: "Pre-bud stage", "One tenth bloom", "50\% blooming" and "Full blooming".

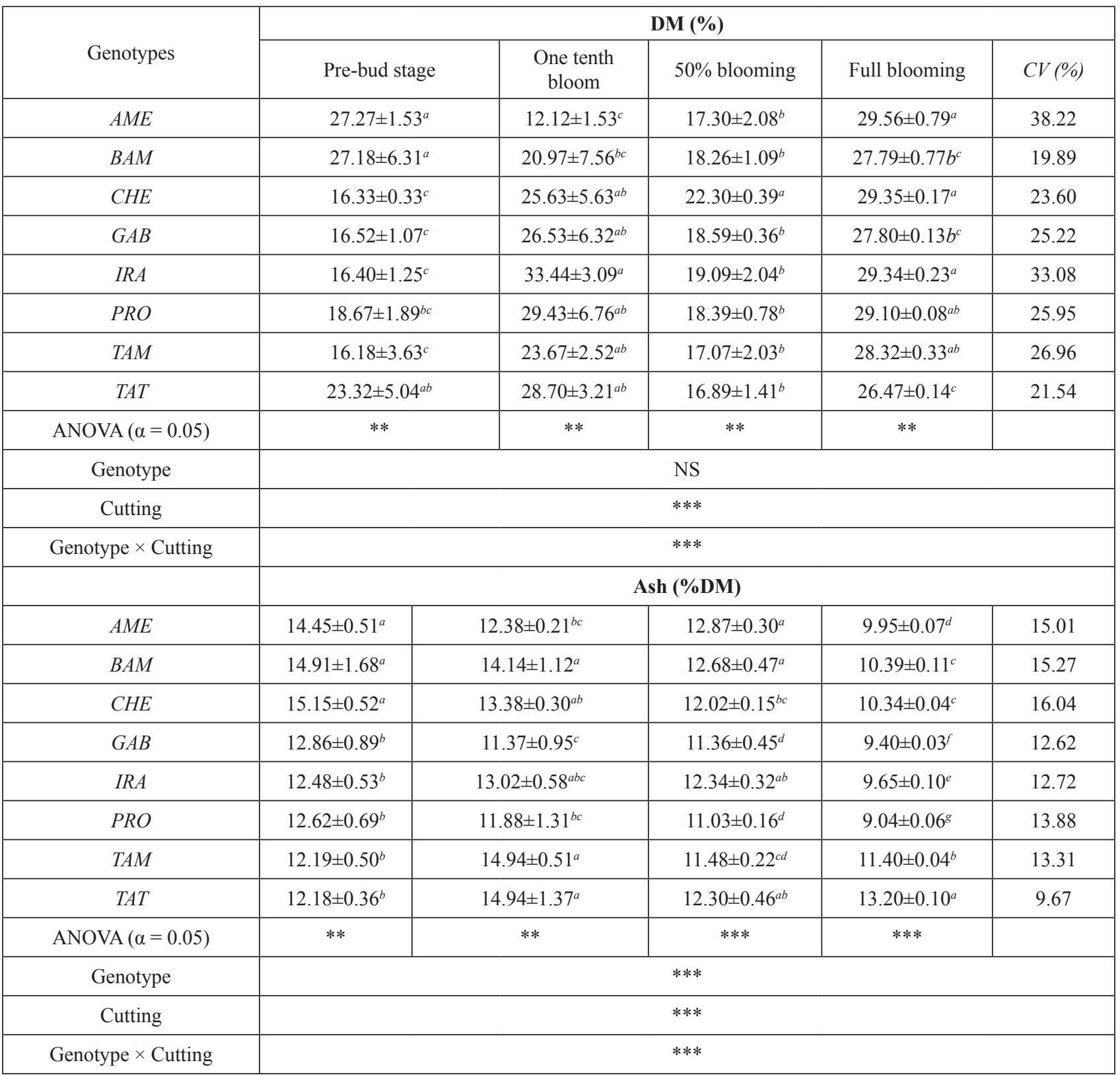

Genotypes were designed by AME: Ameristand801S; BAM: Bami; CHE: Chenini;

GAB: Gabes; IRA: IRA; PRO: Prosementi; TAM: Tamentit; TAT: Tata. Letters $a$ - $g$ denote statistical classes of genotypes obtained using Duncan test, for each trait. Significant differences were designed according to $P$ values by $*: P<0.05, * *: P<0.01,{ }^{* * *}$ :

$P<0.001$ and $N S$ (non-significant): $P>0.05$.

of $G A B$ harvested at $50 \%$ blooming might exceed $6 \mathrm{Mg} \mathrm{ha}^{-1}$ (Fig. 1c). DM yield values for $G A B$ might exceed 2 to 3 folds more than values registered by both of local genotypes CHE and IRA and 1.5 to 2 folds more than those of $B A M$ in case of cuttings at $50 \%$ blooming or after (Fig. 1c-d). Moreover, the evaluation of $\mathrm{DM} \%$ and ash during the first harvest revealed that the highest production of DM was recorded for $A M E$, however in the advanced stage of development, DM decreased, and then increased at the last harvest (Table 4).

\section{Effect of Harvest Time on Nutritional Quality}

The evaluation of total nitrogen contents (Table 5) revealed high significant differences with $\mathrm{G}, \mathrm{C}$ and combined $\mathrm{G} \times \mathrm{C}$ (Table 5). At the first harvest (Prebud stage), $P R O$ ranked first in terms of most elevated content of nitrogen, versus less content was recorded by $G A B$ and CHE. At the third harvest (50\% blooming), $G A B$ recorded the highest contents of nitrogen, with $22.5 \mathrm{mg} \mathrm{g}^{-1} \mathrm{DM}$. However, the $\mathrm{N}$ contents decreased gradually with harvesting times, to show the lowest values at the fourth cutting at Full blooming stage (Table 5). 
Table 5. Evaluation of Nitrogen content of eight genotypes of alfalfa plants, at four different cutting dates: "Pre-bud stage", "One tenth bloom", "50\% blooming" and "Full blooming".

\begin{tabular}{|c|c|c|c|c|c|}
\hline \multirow{2}{*}{ Genotypes } & \multicolumn{5}{|c|}{ Nitrogen $\left(\mathrm{mg} \mathrm{g}^{-1} \mathrm{DM}\right)$} \\
\hline & Pre-bud stage & One tenth bloom & $50 \%$ blooming & Full blooming & $C V(\%)$ \\
\hline$A M E$ & $28.00 \pm 0.28^{a b}$ & $19.46 \pm 0.50^{c d}$ & $19.11 \pm 0.17^{b}$ & $18.02 \pm 0.81^{a}$ & 21.80 \\
\hline$B A M$ & $19.96 \pm 0.64^{c}$ & $19.78 \pm 0.30^{b-d}$ & $17.43 \pm 0.22^{c}$ & $12.80 \pm 0.27^{d}$ & 19.07 \\
\hline CHE & $23.73 \pm 0.18 b^{c}$ & $20.61 \pm 1.15^{a-d}$ & $19.16 \pm 0.41^{b}$ & $14.75 \pm 0.02^{b c}$ & 19.08 \\
\hline$G A B$ & $24.63 \pm 1.80 b^{c}$ & $22.78 \pm 1.56^{a b}$ & $22.52 \pm 0.17^{a}$ & $14.07 \pm 0.20^{\text {cd }}$ & 22.45 \\
\hline $\operatorname{IRA}$ & $21.33 \pm 0.74^{c}$ & $17.69 \pm 0.27^{d}$ & $18.98 \pm 0.33^{b}$ & $15.67 \pm 0.04^{b}$ & 12.88 \\
\hline PRO & $33.47 \pm 4.86^{a}$ & $21.97 \pm 1.26^{a-c}$ & $19.27 \pm 0.11^{b}$ & $15.53 \pm 0.46^{b c}$ & 34.31 \\
\hline TAM & $21.33 \pm 0.71^{c}$ & $23.47 \pm 0.39^{a}$ & $18.41 \pm 0.78^{b c}$ & $16.27 \pm 0.89^{b}$ & 15.96 \\
\hline TAT & $20.47 \pm 1.36^{c}$ & $20.94 \pm 1.37^{a-c}$ & $18.70 \pm 0.48^{b}$ & $13.15 \pm 0.24^{d}$ & 19.54 \\
\hline $\operatorname{ANOVA}(\alpha=0.05)$ & $* *$ & $*$ & $* * *$ & $* * *$ & \\
\hline Genotype & \multicolumn{5}{|c|}{$* * *$} \\
\hline Cutting & \multicolumn{5}{|c|}{$* * *$} \\
\hline Genotype $\times$ Cutting & \multicolumn{5}{|c|}{$* * *$} \\
\hline
\end{tabular}

Genotypes were designed by AME: Ameristand801S; BAM: Bami; CHE: Chenini;

GAB: Gabes; IRA: IRA; PRO: Prosementi; TAM: Tamentit; TAT: Tata. Letters $a$ - $d$ denote statistical classes of genotypes obtained using Duncan test. Significant differences were designed according to $P$ values by *: $P<0.05, * *: P<0.01, * * *: P<0.001$ and $N S$ (non-significant): $P>0.05$.

Besides, our data revealed constant decrease of nitrogen contents along blooming stages of alfalfa, as well as positive a correlation between nitrogen content and leaf/stem ratio versus negative correlation between nitrogen content and plants height (Table 6).

The evaluation of contents of total soluble proteins, free amino acids and total soluble sugars (Figs 2-4) showed significant variations according to $\mathrm{G}, \mathrm{C}$ and $\mathrm{G} \times \mathrm{C}$. While $A M E$ ranked first at one tenth bloom stage, local genotypes $(G A B, C H E$ and $I R A)$ registered the highest rankings in term of total soluble proteins, free amino acids and total soluble sugars at prebud stage. At full blooming stage, contents of free amino acids significantly increased for all genotypes, especially $B A M$ for which the these contents exceeded $2.5 \mathrm{mg} \mathrm{g}^{-1} \mathrm{DM}$ (Fig. 3). Likewise, the analysis of variances for total soluble sugars trait revealed highly significant differences $(P<0.001)$ within harvesting dates, with a particular increase at the third and fourth stages (Fig. 4). Besides, our data reveals an ameliorating effect during the latest growth stage, in terms of content of proteins and free amino acids, particularly for the introduced genotypes ( $A M E, B A M, P R O, T A M, T A T)$ in comparison with local $(G A B, C H E)$ and selected $(I R A)$ genotypes.

Table 6. Correlation coefficients ( $\mathrm{r}$ values, $\alpha=0.05$ ) between all studied agro-morphological and biochemical traits at different growth stages.

\begin{tabular}{|c|c|c|c|c|c|c|c|c|c|c|}
\hline Variables & 1. & 2. & 3. & 4. & 5. & 6. & 7. & 8. & 9. & 10. \\
\hline 1. Plant hight & 1 & & & & & & & & & \\
\hline 2. Number of internodes & $0.797 * * *$ & 1 & & & & & & & & \\
\hline 3. Length of internodes & $0.508 * *$ & 0.074 & 1 & & & & & & & \\
\hline 4. Dry matter yield & $0.586 * * *$ & $0.377 *$ & $0.564 * * *$ & 1 & & & & & & \\
\hline 5. $\% \mathrm{DM}$ & 0.314 & $0.420 *$ & -0.066 & 0.204 & 1 & & & & & \\
\hline 6. Ash & $-0.788 * * *$ & $-0.573 * * *$ & $-0.393 *$ & $-0.414 *$ & -0.232 & 1 & & & & \\
\hline 7. Nitrogen content & $-0.703 * * *$ & $-0.646 * * *$ & -0.275 & -0.305 & $-0.351 *$ & $0.504 * *$ & 1 & & & \\
\hline 8. Total soluble proteins & 0.336 & 0.018 & 0.160 & 0.141 & -0.291 & $-0.445 *$ & -0.339 & 1 & & \\
\hline 9. Free amino acids & 0.074 & -0.132 & 0.123 & 0.028 & $-0.392 *$ & -0.072 & -0.158 & $0.564 * * *$ & 1 & \\
\hline 10. Total soluble sugars & 0.205 & -0.099 & $0.496 * *$ & $0.363 *$ & $-0.428 *$ & -0.123 & -0.083 & 0.248 & 0.290 & 1 \\
\hline
\end{tabular}

Coefficients in bold denote significant correlations with p-values by *: $P<0.05, * *: P<0.01$ and ***: $P<0.001$ 
a)

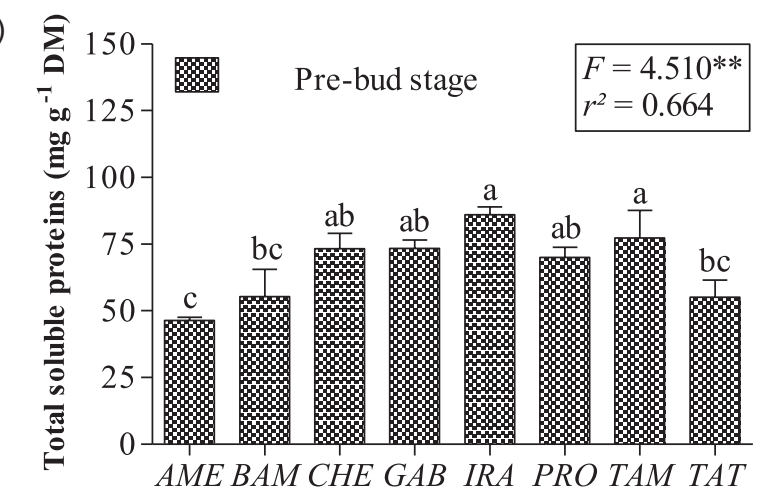

c)

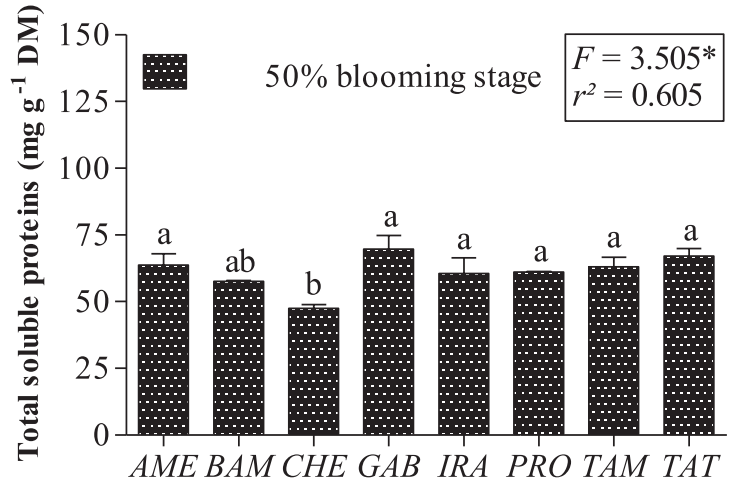

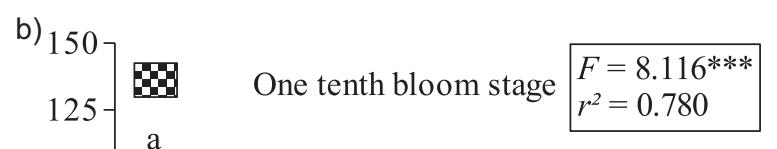

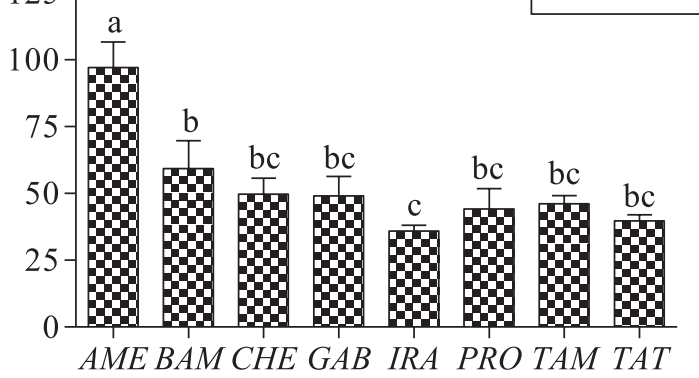

d)

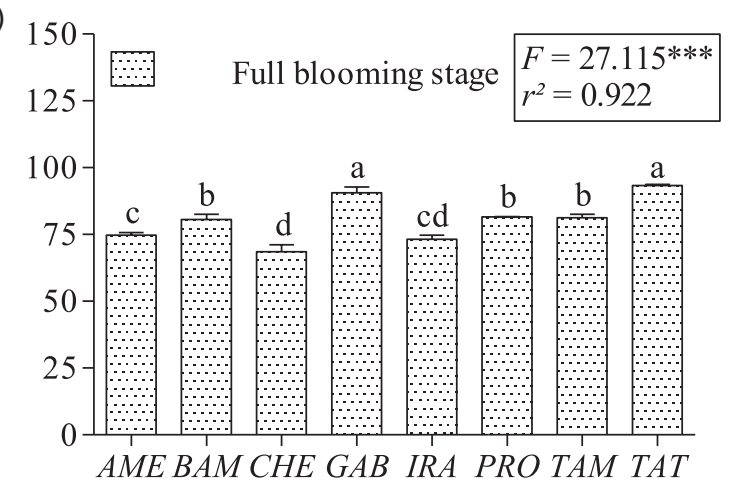

Fig. 2. Changes in total soluble protein contents of eight genotypes of alfalfa plants at four different cutting dates: a) Pre-bud stage, b) One tenth bloom, c) 50\% blooming and d) Full blooming. Genotypes were designed by AME: Ameristand801S; BAM: Bami; CHE: Chenini; GAB: Gabes; IRA: IRA; PRO: Prosementi; TAM: Tamentit; TAT: Tata. " $F$ " denote values of Fisher test. Letters a-f denote statistical classes of genotypes obtained using Duncan test. Significant differences were designed according to $P$ values by *: $P<0.05, * *: P<0.01$ and $* * *: P<0.001$.

a)

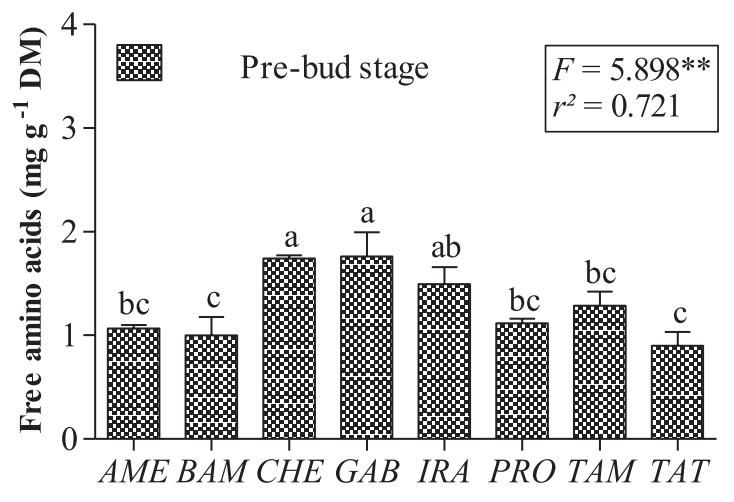

c)

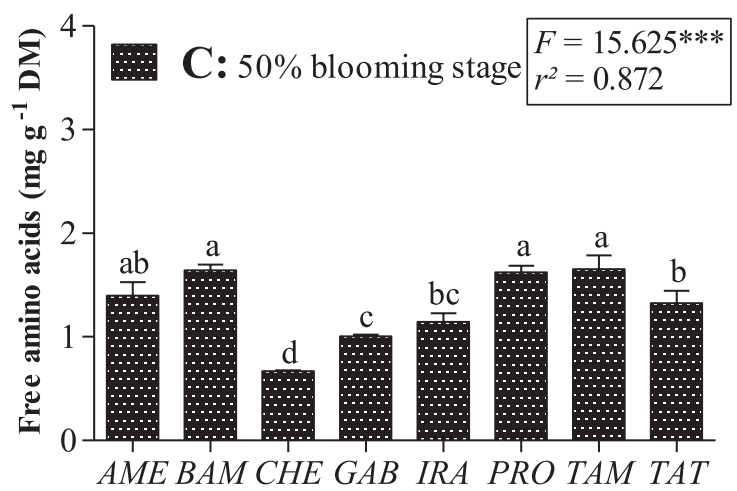

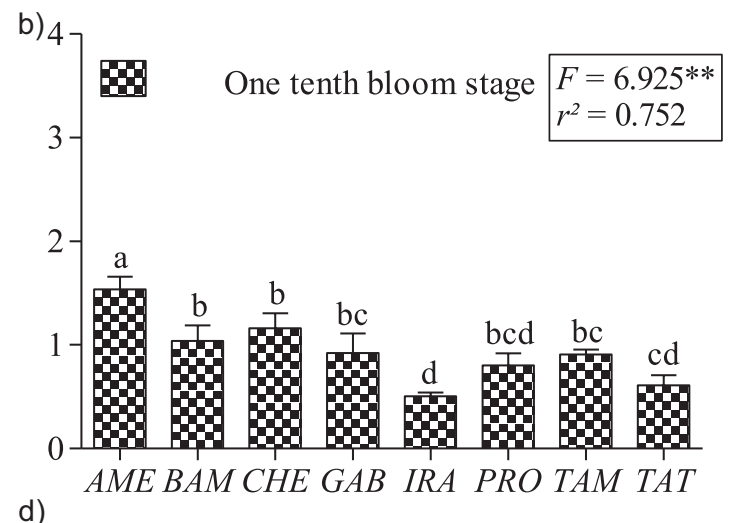

d)

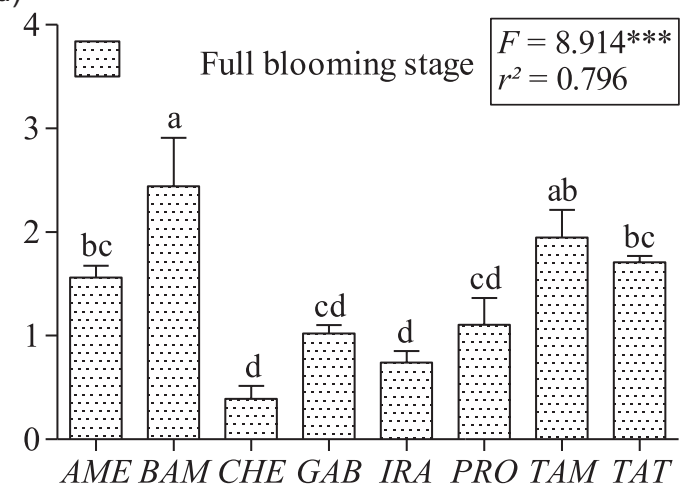

Fig. 3. Changes in free amino acid contents of eight genotypes of alfalfa plants at four different cutting dates: a) Pre-bud stage, b) One tenth bloom, c) 50\% blooming and d) Full blooming. Genotypes were designed by AME: Ameristand801S; BAM: Bami; CHE: Chenini; GAB: Gabes; IRA: IRA; PRO: Prosementi; TAM: Tamentit; TAT: Tata. " $F$ " denote values of Fisher test. Letters a-f denote statistical classes of genotypes obtained using Duncan test. Significant differences were designed according to $P$ values by *: $P<0.05, * *: P<0.01$ and $* * *: P<0.001$. 
a)

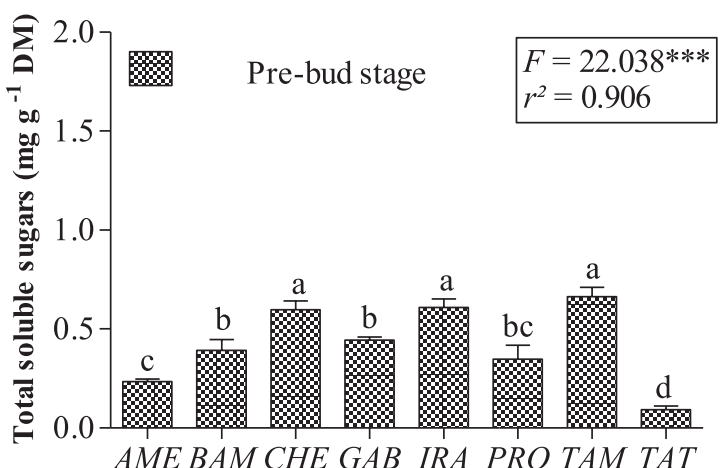

c)

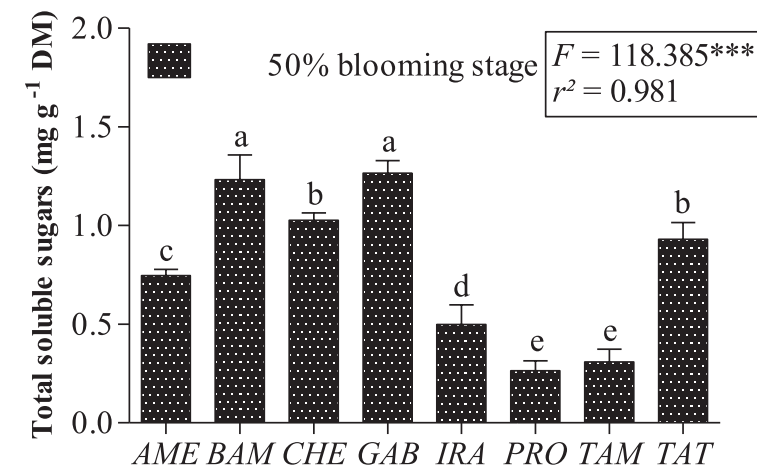

b) 2.0

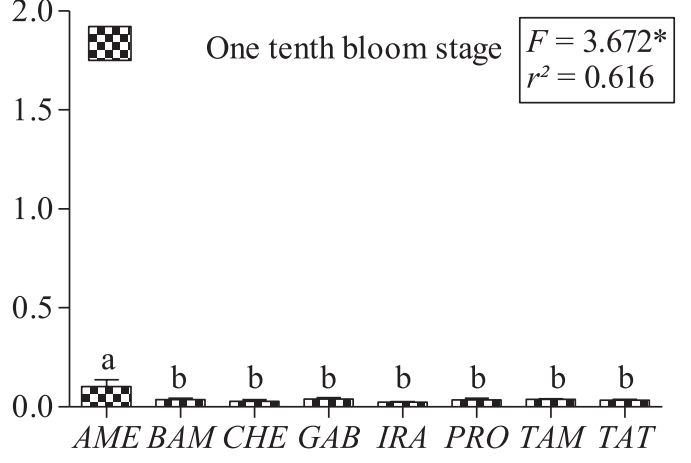

d) 2.0

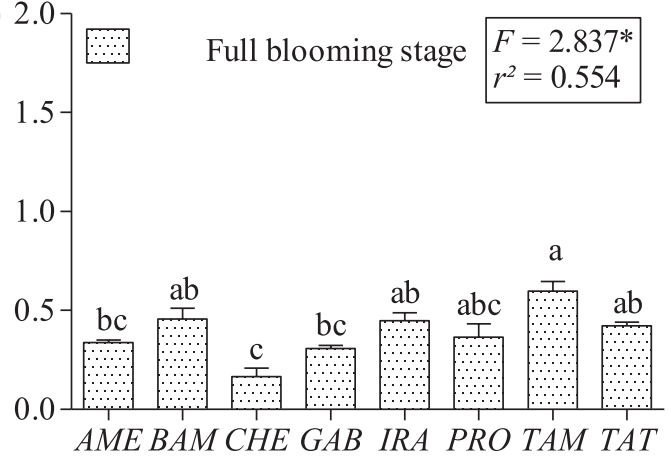

Fig. 4. Changes in total soluble sugar contents of eight genotypes of alfalfa plants at four different cutting dates: a) Pre-bud stage, b) One tenth bloom, c) 50\% blooming and d) Full blooming. Genotypes were designed by AME: Ameristand801S; BAM: Bami; CHE: Chenini; GAB: Gabes; IRA: IRA; PRO: Prosementi; TAM: Tamentit; TAT: Tata. " $F$ " denote values of Fisher test. Letters $a-e$ denote statistical classes of genotypes obtained using Duncan test. Significant differences were designed according to $P$ values by $*: P<0.05,{ }^{* *}: P<0.01$ and ***: $P<0.001$.

\section{Optimization of Harvest Time with Multivariate Analysis and Clustering of Alfalfa Genotypes}

The multi-criteria classification revealed diverse ratios and different correlations between yield and the biochemical traits coupled to harvest time (Table 6). The agro-morphological and biochemical traits combined analyses allowed to establish the overall similarity matrix via the dendrogram representations (Fig. 5), and to classify alfalfa genotypes according to harvest time using the principal component analysis (PCA) (Fig. 5a). Taking in account all data, five main clusters reflecting the genetic dissimilarity and similarity within the eight genotypes were determined (Fig. 5b).

\section{Discussion}

Little progress has been achieved to improving yield potential and nutritional quality of forage of alfalfa in arid regions because of the potential interference of different environmental stress factors with alfalfa genotypes [14]. In our study, we investigated both genetic variability (eight genotypes of alfalfa) and harvesting time (stage of growth), separately and in combination for better yield and nutritional quality.

The evaluated eight alfalfa genotypes showed differential agro-morphological traits at different harvesting times. Basically, all genotypes registered reduced growth (Plant height, Number and length of internodes, DM yield, DM\% and ash) during fall dormancy to pre-bud stage, followed by the dynamic regrowth of alfalfa plants, the recovery, the renewal and the resumption of biological and metabolic activities of the preexistant buds, together with the novo synthesized and newly formed buds at one tenth blooming stage. All genotypes reached maximum levels of growth at last stages (50\% blooming and full blooming: third and fourth cuttings), despite the interference of mortality factor. Generally, with the advancement of growth stages, from early bud stage until the early bloom stage, the production of whole plant increased continuously, which increased the biomass production. With the emergence of the first flowers, the leaf production decreased, while the total biomass tended to stabilize. Until the stage of $10 \%$ blooming, alfalfa plants showed optimal development and biomass, which reduced DM production. However, at 50\% blooming, full blooming and pods filling stages resulted in the lignification of cell walls and fibers and the increase of biomass production, concomitant with the reduction of mineral composition, ash and organic matter contents, thereby contributing to the limitation of digestibility and protein quality [15]. These findings were explained in other studies by the percentages of stems and leaves of the total plant biomass $[1,7]$.

These differential agro-morphological characteristics among alfalfa genotypes may suggest eventual shifts in the metabolic and physiological pathways under 
a) Principal components analysis

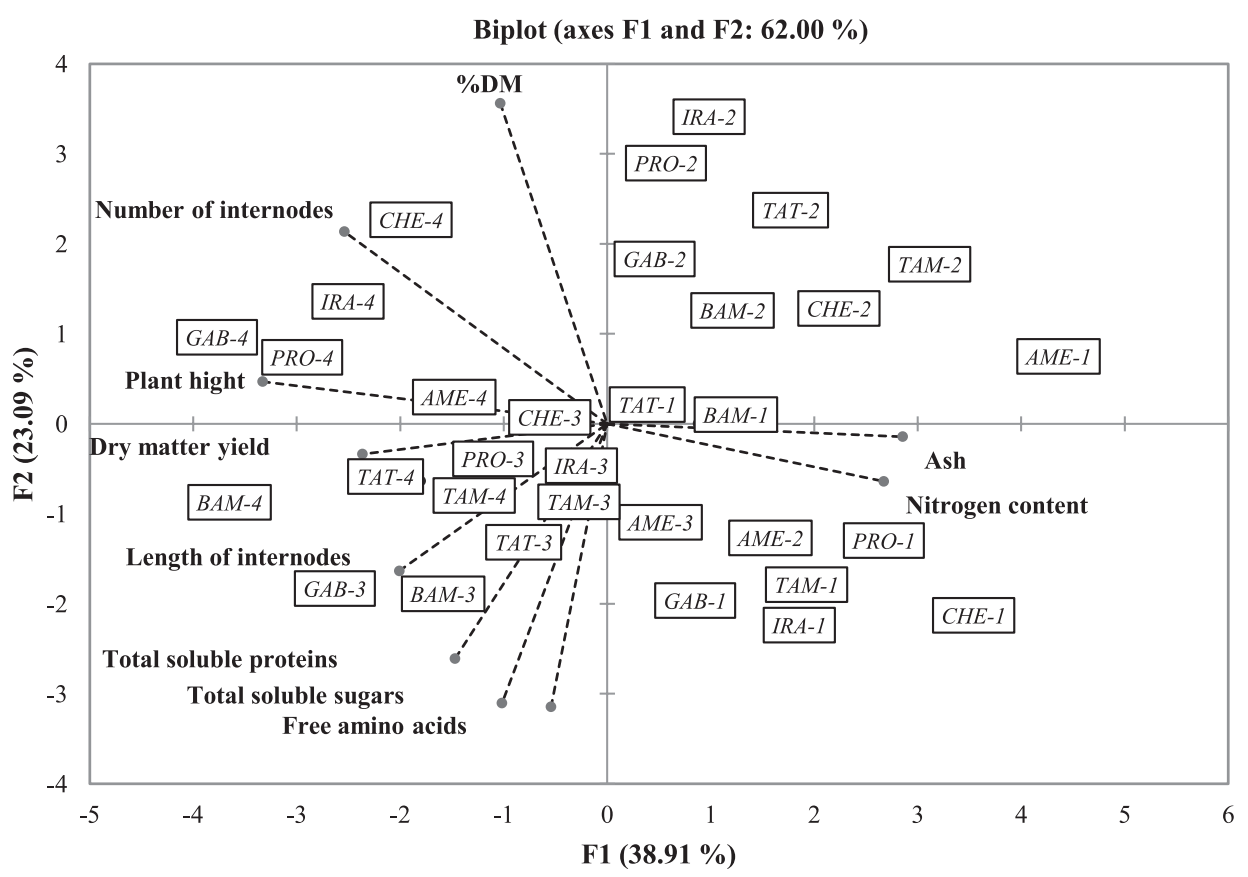

b) Hierarchical cluster using Pearson correlation similarity method

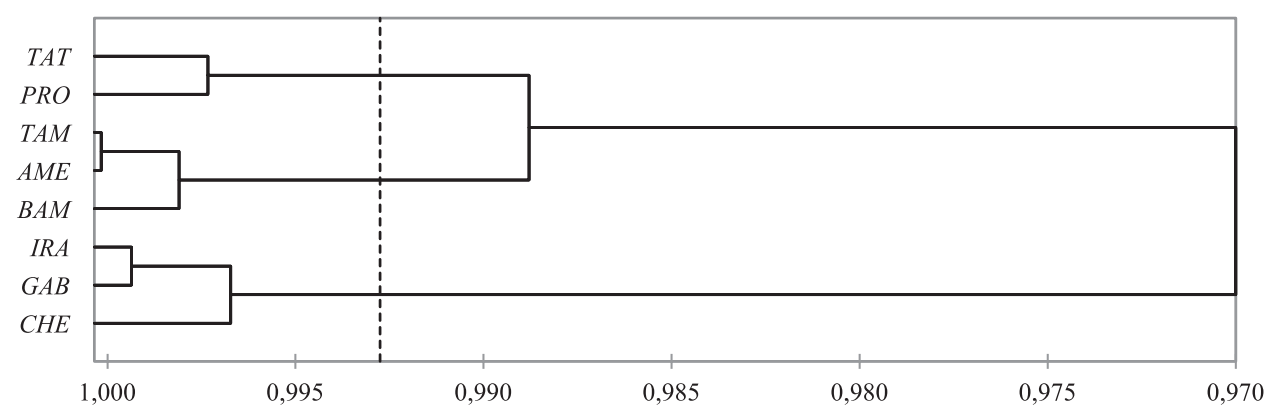

Fig. 5. a) Principal component analysis representations of global results of all agro-morphological and biochemical traits for eight genotypes of alfalfa plants collected at four different cutting dates; 1: "Pre-bud stage", 2: "One tenth bloom", 3: "50\% blooming" and 4: "Full blooming". b) Hierarchical clusters for degree of similarity among studied genotypes of alfalfa plants on the basis of means data resulting from averages of four cutting dates. Genotypes were designed by AME: Ameristand801S; BAM: Bami; CHE: Chenini; GAB: Gabes; IRA: IRA; PRO: Prosementi; TAM: Tamentit; TAT: Tata.

stressful conditions [5, 16-20]. This may suggest the different aptitude of tolerance of alfalfa genotypes to the adverse arid conditions, thus leading to the changes in yield and nutritional quality. This hypothesis was confirmed by the important changes of the contents of total nitrogen with the phenological cycle, which agree with other reports $[1,5,7]$. Besides, alfalfa genotypes seem to display individual aptitudes of adaptability to arid environment depending on the harvest time. Indeed, an ameliorating effect was observed during the latest growth stage, in terms of content of proteins and free amino acids, particularly for the introduced genotypes ( $A M E, B A M, P R O, T A M, T A T)$ in comparison with local $(G A B, C H E)$ and selected $(I R A)$ genotypes. The mechanism by which the most tolerant genotypes seem to exhibit may be via (i) the mobilization of reserves of proteins during winter and beginning of spring periods, or (ii) the synthesis of amino acids, such as proline, as well as soluble proteins that can be involved in the protection against stress. For example in many studies, the synthesis of heat choc proteins, antioxidant enzymes, osmotically active metabolites, specific proteins and certain free radical enzymes were shown to control ion and water flux and support scavenging of oxygen radicals [21-27], thus allowing to confront and mend the disregulations at metabolism, molecular and cellular levels. Among other examples in literature, proline was shown to improve tolerance to stress including drought, salinity and heat [2427]. It was also evidenced that proline synthesis was induced in stressed plants which in turn imparts stress tolerance by maintaining cell turgor or osmotic balance, 
stabilizing membranes and proteins thereby preventing electrolyte leakage and protein structure alteration, ROS scavenging. Proline also functions as redox balancer, cytosolic $\mathrm{pH}$ buffer and molecular chaperon, metal chelator, antioxidative defense molecule and signaling molecule [22, 25]. Moreover, the elevation of sugar content is considered an indicator of stress condition, allowing to maintain the hydraulic pression in cells and to protect cellular structures and functions, in order to cope with sustained environmental stress factors (water deficit, drought, extreme temperature, etc.) [28]. For example, [23] showed that sugar metabolism contributed to desiccation tolerance. Indeed, sugars accumulated during dehydration allowing to protect macromolecules and membranes and to scavenge ROS. In general, under stress conditions, alfalfa increased the expression of genes encoding several metabolic enzymes involved in different pathways, such as cell wall modifcation, proline synthesis pathway, ROS scavenging [29, 32].

In our study, the tolerance capacity at pre-bud stage during winter season seems to be developed first by the selected (IRA) and local (GAB, CHE) genotypes then by introduced (TAM, PRO) genotypes, except TAT. All described data suggests that studied alfalfa genotypes responded differently to cutting dates, via the improvement of possible tolerance pathways to stress environment especially at advanced stage of development. This was also corroborated by the correlations brought to light between agromorphological, biochemical traits and yield, which allowed classifying the genotypes into different clusters. Our results also agree with other studies reporting negative correlation between nutritive value of forage and maturity of plants [33], as well as DM and stem length [34], and (ii) between nutritional quality and productivity of forage with plant developmental stages and environmental condition $[35,36]$. The differential response of alfalfa genotypes was actually interesting in our study because this genetic variability may offer new tools not only to improve tolerance of alfalfa to arid conditions, but also promote heterosis to develop forage yield and nutritional quality at any harvesting time. In fact, other researchers recommended to harvest alfalfa at pre-bud to one-tenth bloom stages, in order to guarantee interesting forage yields coupled to a good nutritional quality [37]. In addition, the leaf DM production decreases after the start of blooming, which may result in poorer quality of forage, while full blooming stage shows stabilization of plant growth versus intensive allocation of biomass towards flower production. Besides, other authors showed that the mobilization of reserves and transfer of nutrients from the sink organs (leaves and shoots) to target organs (flowers and seeds) were proved to affect the forage quality [38]. Hence, it was commended harvesting at an advanced stage of vegetation (30 to $50 \%$ blooming) to enable plants to accumulate reserve substances in the crown, which are necessary for regeneration, productivity and longevity of alfalfa crops [39]. Nevertheless, in our present trial, we confirmed that local or native genotypes "GAB, CHE" of alfalfa, adapted to oasis micro-climate, exhibited better tolerance to outside oases arid conditions [37]. Therefore, recent studies have established crops of "GAB" alfalfa as the most adapted to salinity and water deficit [34]. This tolerance ability may be due to the fact that $G A B$ is not subjected to dormancy periods. However, the intriguing selected "IRA" and introduced "PRO", "BAM", and "TAM" genotypes may offer innovative tools when cultured together, because such diverse population can boost yield and nutritive quality at whatever stage of harvesting, and develop performance of local genotypes.

\section{Conclusions}

Overall, the adaptive responses of eight genotypes of alfalfa plants grown under arid conditions seem to be resulting of some biochemical and metabolic changes, including proteins and osmolytes that confer tolerance mechanisms. This study brings evidence of different interesting performances of genotypes "IRA, PRO, BAM, and TAM" together with genotype "GAB". This genetic variation or variability may offer new tools to improve tolerance of alfalfa to arid conditions, in addition to improve both forage yield and nutritional quality. This may allow in future studies to investigate the possibility to use these genotypes in culture or in breeding programs, in attempt to minimize inbreeding risk and to improve performance of native genotypes, while favoring heterosis phenomenon, as well as preserving and improving genetic patrimony. In addition, in order to improve breeding selection efficiency is to identify genetic loci associated with abiotic tolerance and develop diagnostic markers closely linked to the tolerance loci for marker-assisted selection.

\section{Acknowledgements}

This work was supported by the Dry Land and Oases Cropping Laboratory, Arid Land Institute of Medenine (IRA). We thank Prof. Paolo Annicchiarico and Prof. Luciano Pecetti from the Research Centre for Fodder Crops and Dairy Productions (CREA-FLC), LodiITALY for introduced genotypes seeds. We thank Mr. Hedi Yahia and Mr. Mohamed Debara (technicians at IRA) for their assistance in experiments. We also acknowledge the help and support of the direction and the technicians of the Insitute of Applied Biology of Medenine (ISBAM).

\section{Conflict of Interest}

The authors declare no conflict of interest. 


\section{References}

1. ANNICCHIARICO P., BARRETT B., BRUMMER E.C., JULIER B., MARSHALL A.H. Achievements and challenges in improving temperate perennial forage legumes. Crit Rev Plant Sci, 34 (1-3), 327, 2015.

2. BEN RHOUMA H., TASKI-AJDUKOVIC K., ZITOUNA N., SDOUGA D., MILIC D., TRIFI-FARAH N. Assessment of the genetic variation in alfalfa genotypes using SRAP markers for breeding purposes. Chil J Agr Res, 77 (4), 332, 2017.

3. HOJILLA-EVANGELISTA M.P., SELLING G.W., HATFIELD R., DIGMAN M. (2017) Extraction, composition, and functional properties of dried alfalfa (Medicago sativa L.) leaf protein. J Sci Food Agr, 97 (3), 882, 2017.

4. TLAHIG S., BEN KHALED A., LOUMEREM M. (2017) Evaluation of forage biomass and seed yield among alfalfa progenies bred for adaptation to Tunisian outside oases conditions. Glo Adv Res J Agric Sci, 6 (6), 141, 2017.

5. MAURIES M. La luzerne : Culture, récolte, conservation et utilisation. Editions France Agricole. pp 2672003.

6. TUCAK M., POPOVIC S., CUPIC T., KRIZMANIC G. (2017) Drought stress responses of alfalfa (Medicago sativa L.) breeding populations. Rom Agric Res, 34, 25, 2017.

7. ORLOFF S.B., PUTNAM D.H. Forage quality In C. G. P. and testing. Summers, D.H. (Ed.), Irrigated alfalfa management for Mediterranean and desert zones, University of California Agriculture and Natural Resources. Publication 8302: 1, 2007.

8. MEZNI M., ALBOUCHI A., BIZID E. (2002) Effect of salinity on sodium and chloride uptake, proline and soluble carbohydrate contents in three alfalfa varieties. J Agric Vet Sci, 1 (6), 1, 2002

9. BANSAL O.P. The Influence of potentially toxic elements on soil biological and chemical properties. In Metals in Soil - Contamination and Remediation; Zinnat Ara Begum, Ismail M. M. Rahman, Hiroshi Hasegawa Eds. Intechopen, London, United Kingdom, 455, 2019.

10. BRADFORD M.M. A rapid and sensitive method for the quantization of microgram quantities of protein utilizing the principle of protein-dye binding. Anal Biochem, 72 (6), 248, 1976.

11. MOORE S., STEIN W.H. A modified ninhydrin reagent for the photometric determination of amino acids and related compounds. J Biol Chem, 211 (6), 907, 1954.

12. MCCREADY R.M., GUGGOLZ J., SILVIERA V., OWENS H.S. (1950) Determination of starch and amylose in vegetables. Anal Chem, 22 (9), 1156, 1950.

13. THIEX N.J., MANSON H., ANDERSON S. PERSSON J.A. et al. Determination of Crude Protein in Animal Feed, Forage, Grain, and Oilseeds by Using Block Digestion with a Copper Catalyst and Steam Distillation into Boric Acid: Collaborative Study. Journal of AOAC International, 85 (2), 309, 2002.

14. ANNICCHIARICO P., PECETTI L., TAVA A. (2013) Physiological and morphological traits associated with adaptation of lucerne (Medicago sativa) to severely drought-stressed and to irrigated environments. Ann Appl Biol, 162 (1), 27, 2013

15. TURK M., ALBAYRAK S., BOZKURT Y. (2014) Seasonal trends in chemical composition of different artificial pastures. Turk J Field Crops, 19 (1), 53, 2014.
16. RIMI F., MACOLINO S., ZILIOTTO U. Relationships between dry matter yield, forage nutritive value, and some canopy parameters of alfalfa crop. Grassland in a changing world. Proceedings of the $23^{\text {rd }}$ General Meeting of the European Grassland Federation, Kiel, Germany, 29 ${ }^{\text {th }}$ August - $2^{\text {nd }}$ September 2010, 548, 2010.

17. IDUPULAPATI M., JOHN W., STEPHEN E., WALTER J.H. Root adaptations to soils with low fertility and aluminium toxicity. Ann Bot, 118 (4), 593, 2016.

18. LEI Y., HANNOUFA A., YU P. The use of gene modifcation and advanced molecular structure analyses towards improving alfalfa forage. Int J Mol Sci, 18 (2), 298, 2017.

19. LEI Y., XU Y., HETTENHAUSEN C., LU C., SHEN G., ZHANG C., LI J., SONG J., LIN H., WU J. Comparative analysis of alfalfa (Medicago sativa L.) leaf transcriptomes reveals genotype-specifc salt tolerance mechanisms. BMC Plant Biol, 18, 35, 2018.

20. SONG Y., LV J., MA Z., DONG W. (2019) The mechanism of alfalfa (Medicago sativa L.) response to abiotic stress. Plant Growth Regul, 89, 239, 2019.

21. PARVAIZ A., SATYAWATI S. (2008) Salt stress and phyto-biochemical responses of plants. Plant Soil and Environ, 54 (3), 89, 2008.

22. SHAMSUL H., QAISER H., ALYEMENI M.N., WANI A.S., PICHTEL J., AHMAD A. Role of proline under changing environments. Plant Signal Behav, 7 (11), 1456, 2012.

23. ZHANG Q., SONG X., BARTELS D. Enzymes and metabolites in carbohydrate metabolism of desiccation tolerant plants. Proteomes, 4, 40, 2016.

24. YU J., LI R., FAN N., YANG Z., HUANG B. Metabolic pathways involved in carbon dioxide enhanced heat tolerance in bermudagrass. Front Plant Sci, 8, 1506, 2017.

25. IQBAL M.J. Role of osmolytes and antioxidant enzymes for drought tolerance in Wheat. In Global Wheat Production; Shah Fahad, Abdul Basir Eds., Intechopen, London, United Kingdom, 551, 2018.

26. ASHRAFI M., AZIMI-MOQADAM M.R., MORADI P., MOHSENIFARD E., SHEKARI F., KOMPANY-ZAREH M. Effect of drought stress on metabolite adjustments in drought tolerant and sensitive thyme. Plant Physiol Biochem, 132, 391, 2018.

27. SADAK M.S. Physiological role of trehalose on enhancing salinity tolerance of wheat plant. Bull Natl Res Cent, 43, 53, 2019.

28. BIDGOLI R.D., RANJBARFORDOEI A. Vegetation types and rangeland species nutritional values and forage quality indicators at various phonological stages. Int $\mathrm{J}$ Plant Physiol Biochem, 5 (2), 16, 2013.

29. AN Y.M., SONG L.L., LIU Y.R. et al. De novo transcriptional analysis of Alfalfa in response to salinealkaline stress. Front Plant Sci, 7, 931, 2016.

30. MA Q., KANG J., LONG R. et al. Comparative proteomic analysis of alfalfa revealed new salt and drought stressrelated factors involved in seed germination. Mol Biol Rep, 44, 261, 2017.

31. XIONG J., SUN Y., YANG Q. et al. Proteomic analysis of early salt stress responsive proteins in alfalfa roots and shoots. Proteome Sci, 15,19, 2017.

32. ZHANG Q., LIU X., ZHANG Z. et al. (2019) Melatonin improved waterlogging tolerance in alfalfa (Medicago sativa) by reprogramming polyamine and ethylene metabolism. Front Plant Sci, 10, 44, 2019. 
33. REBOlÉ A., AlZUetA C., ORTIZ L., BARRO C., RODRÍGUEZ M.L., CABALLERO R. Yields and chemical composition of different parts of the common vetch of flowering and at two seed filling states. Span J Agric Res, 2 (4), 550, 2004.

34. BENABDERRAHIM M.A., HADDAD M., FERCHICHI A. Diversity of Lucerne (Medicago Sativa L.) Populations in South Tunisia. Pak J Bot, 41 (6), 2851, 2009.

35. LATRACH L., FARISSI M., MOURADI M., MAKOUDI B. (2014) Growth and nodulation of alfalfa rhizobia symbiosis under salinity: electrolyte leakage, stomatal conductance, and chlorophyll fluorescence. Turk J Agric For, 38, 320, 2014.

36. STAVARACHE M., SAMUIL C., POPOVICI C.I., TARCAU D., VINTU V. The Productivity and Quality of Alfalfa (Medicago sativa L.) in Romanian Forest Steppe. Not Bot Horti Agrobot Cluj Napoca, 43 (1), 179, 2015.
37. LOUMEREM M., TLAHIG S., ANNICCHIARICO P., PECETTI L., SOUSA M.M.T. Breeding of local alfalfa (Medicago sativa L.) "Gabssia" for yield and improving tolerance to water salinity and winter dormancy in the arid regions of Tunisia. Paper presented in the Fifth International Scientific Agricultural Symposium "Agrosym 2014" Jahorina, Serbia, October 23-26: 324, 2014.

38. LARBI A., ABD EL-MONEIM A.M., NAKKOUL H., JAMMAL B., HASSAN S. Intra-species variations in yield and quality in Lathyrus species: 1 . Grasspea ( $L$. sativus L.). Anim Feed Sci Tech, 161 (1), 9, 2010.

39. ORLOFF S.B., MARBLE V.L. Harvest Management. In Intermountain alfalfa management. Publication 3366; ORLOFF S.B., CARLSON H.L., TEUBER L.R. Eds.; University of California: Library of Congress Catalog Card No. 94-61790, California, USA, pp 103, 1997. 